Syntax Literate: Jurnal Ilmiah Indonesia p-ISSN: 2541-0849

e-ISSN: 2548-1398

Vol. 6, No. 2, Februari 2021

\title{
EFEKTIVITAS BIAYA MULTIVITAMIN PADA MASA KEHAMILAN TRISEMESTER III PASIEN RUMAH SAKIT IBU DAN ANAK KOTA BANDUNG
}

\author{
Indah Laily Hilmi, Lely Sulfiani Saula, Ellin Rachamwati dan Yuli Yuliani \\ Universitas Singaperbangsa Karawang, Indonesia \\ Rumah Sakit Humana Prima Bandung, Indonesia \\ Email: indah.laily@fkes.unsika.ac.id, lely.sulfiani@fkes.unsika.ac.id, \\ lyn_ellin@yahoo.com dan lianiyuli10@gmail.com
}

\begin{abstract}
Multivitamins that contain Vitamins, Minerals, and Folic Acid function to supplement nutrition in the third trimester of pregnancy. Pregnancy Trisemester III is the final trimester, pregnancy in this period of fetal development is in the range of 28-40 weeks and the fetus is at the stage of refinement.In this period the nutritional and nutritional needs of the mother's body and fetal development are very important. The purpose of this study was to determine the picture of therapy and the cost-effectiveness of multivitamin drugs for the fetus.This research is retrospective and conducted using pharmacoeconomic methods, which is a costeffectiveness analysis using multiple multivitamin drugs for fetuses in determining the cost-effectiveness of Tri-Semester III Pregnancy patients in one of Bandung's Mother and Child Hospitals.The study was conducted on 104 patients and the outcome statistical test results with the one way ANOVA test showed all significant values $<0.05$, meaning that there were differences in outcome in the groups tested, or the administration of all types of different multivitamin tests had a significant effect on outcome.Multivitamin therapy with the lowest ACER is Prenamia® IDR. $512.19 / \mathrm{gr}$.
\end{abstract}

Keywords: multivitamin; farmakoekonomi; pregnac.

\begin{abstract}
Multivitamin yang mengandung Vitamin, Mineral, dan Asam Folat berfungsi melengkapi nutrisi pada kehamilan trisemester III. Kehamilan Trisemester III adalah Trisemester akhir, kehamilan pada periode ini perkembangan janin pada rentang 28-40 minggu dan janin berada pada tahap penyempurnaan. Pada periode ini kebutuhan gizi dan nutrisi bagi tubuh ibu dan perkembangan janin sangatlah penting. Tujuan penelitian ini adalah untuk mengetahui gambaran terapi dan efektivitas biaya obat multivitamin untuk janin. Penelitian ini bersifat retrospektif dan dilakukan dengan menggunakan metode farmakoekonomi yaitu analisis efektivitas biaya yang menggunakan beberapa obat multivitamin untuk janin dalam menentukan efektivitas biaya pada pasien Kehamilan Trisemester III di salah satu Rumah Sakit Ibu dan Anak Kota Bandung. Penelitian dilakukan terhadap 104 pasien hasilnya bahwa pasien ibu hamil terbanyak pada penelitian Trisemester III paling banyak berusia 26-30 tahun. Terapi multivitamin dengan rasio efektivitas
\end{abstract}


biaya (REB) terendah yaitu Prenamia ${ }^{\circledR}$ Rp. 512.19/gr dan hasil uji statistik outcome dengan uji one way anova menunjukkan semua nilai signifikan $<0,05$, artinya terdapat perbedaan outcome pada kelompok yang diuji, atau pemberian semua jenis multivitamin uji yang berbeda berpengaruh signifikan terhadap outcome.Terapi multivitamin dengan REB terendah yaitu Prenamia ${ }^{\circledR}$ Rp. 512.19/gr.

Kata Kunci: multivitamin; farmakoekonomi; kehamilan

\section{Coresponden Author}

Email: indah.laily@ fkes.unsika.ac.id Artikel dengan akses terbuka dibawah lisensi

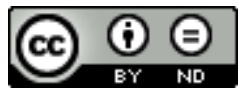

\section{Pendahuluan}

Kehamilan adalah masa dimulai dari konsepsi sampai lahirnya janin, kehamilan berlangsung selama 280 hari (40 minggu atau 9 bulan 7 hari ) di hitung dari hari pertama haid terakhir (HPHT) (Altahira, 2014). Kehamilan trisemester III adalah trisemester akhir kehamilan pada periode ini pertumbuhan janin dalam rentang waktu 28-40 minggu dan janin berada pada tahap penyempurnaan (Manuaba, Manuaba, \& Manuaba, 2007). Menurut profil kesehatan tahun 2018 pelayanan kesehatan ibu hamil harus memenuhi frekuensi minimal di tiap trimester. Pada periode ini kebutuhan gizi dan nutrisi bagi tubuh ibu dan perkembangan janin sangatlah penting (Maulana, 2008).

Gizi memegang peranan penting dalam siklus hidup manusia. Masa kehamilan merupakan periode yang sangat menentukan kualitas Sumber Daya Manusia (SDM) di masa depan, karena tumbuh kembang anak sangat ditentukan oleh kondisinya saat masa janin dalam kandungan. Pada saat di dalam kandungan, janin akan tumbuh dan berkembang melalui pertambahan berat badan dan panjang badan, perkembangan otak serta organ-organ lainnya seperti jantung, hati, dan ginjal. Kekurangan gizi pada ibu hamil dapat mengakibatkan Bayi Berat Lahir Rendah (BBLR). BBLR ialah bayi baru lahir yang berat badannya saat lahir kurang dari 2500 gram (RI, 2012). Saat ini BBLR masih tetap menjadi masalah dunia khususnya di negara-negara berkembang. Di Indonesia pada tahun 2010, prevalensi BBLR sebesar 8,8 persen. Kejadian BBLR ini, besar kemungkinan berasal dari ibu hamil dengan kondisi kurang energi, terutama kekurangan gizi dan nutrisi pada saat kehamilan trisemester III (RI, 2012). Kehamilan trisemester III adalah trisemester akhir kehamilan pada periode ini pertumbuhan janin dalam rentang waktu 28-40 minggu dan janin berada pada tahap penyempurnaan (Manuaba et al., 2007). Pada periode ini kebutuhan gizi dan nutrisi bagi tubuh ibu dan perkembangan janin sangatlah penting (Maulana, 2008). Masalah kesehatan mental selama kehamilan pada ibu hamil (Glynn, Maclean, Forte, \& Cohen, 2009) dan Stres kerja baik secara fisik, psikologis, atau keduanya (Hobel \& Culhane, 2003) mempengaruhi BBLR. Berdasarkan laporan Dinas Kesehatan bayi baru lahir di Jawa Barat tahun 2016 sebanyak 921.521 jiwa, atau 103,9\% dari perkiraan jumlah lahir hidup, dari penimbangan tersebut ditemukan bayi dengan berat badan BBLR tidak hanya dapat 
terjadi pada bayi prematur, tapi juga pada bayi cukup bulan (Dinas Kesehatan, 2016). Persentasi BBLR di Jawa Barat antara 0,1 - 5,7 dan 2,2\% berasal dari jumblah bayi yang ditimbang, jumlah BBLR Kota Bandung sebesar 1,8\%. Masalah BBLR terutama pada kelahiran prematur terjadi karena ketidakmatangan sistem organ pada bayi tersebut, bayi berat lahir rendah mempunyai kecenderungan kearah peningkatan terjadinya infeksi dan mudah terserang komplikasi (Dinas Kesehatan, 2016). Bayi BBLR dapat berakibat jangka panjang terhadap tumbuh kembang anak di masa yang akan datang. Dampak dari BBLR ini adalah pertumbuhan akan lambat, kecenderungan memiliki penampilan intelektual yang lebih rendah dari bayi yang lahir berat badannya normal. Bayi BBLR dapat mengalami gangguan mental dan fisik pada usia tumbuh kembang selanjutnya, sehingga membutuhkan biaya perawatan yang tinggi (Little, Keenan, Niermeyer, Singhal, \& Lawn, 2011).

Kejadian BBLR dapat terjadi di berbagai rumah sakit, diantaranya di salah satu Rumah Sakit Ibu dan Anak Kota Bandung.Bermula sebuah Balai Pengobatan pada tahun 2000. Balai Pengobatan ini berkembang menjadi rumah bersalin pada tahun 2009, dan pada bulan Januari 2012 telah berubah statusnya menjadi salah satu Rumah Sakit Ibu dan Anak Kota Bandung. Salah satu Rumah Sakit Ibu dan Anak di Kota Bandung BBLR termasuk kategori sebagai salah satu kasus dalam sepuluh besar. Data tahun 2018 menunjukan kejadian BBLR sebesar 4,7\%. Untuk menurunkan angka BBLR dengan memberikan obat multivitamin yang biasa diberikan kepada ibu hamil trisemester III kebanyakan menggunakan Folamil Genio ${ }^{\circledR}$, Iberet ${ }^{\circledR F}$ Folic 500 dan Prenamia ${ }^{\circledR}$. Dimana ketiga alternatif multivitamin tersebut berfungsi melengkapi nutrisi (vitamin, mineral dan asam folat) pada kehamilan trisemester III dan membantu perkembangan janin dalam kandungan dengan dosis pemberian dalam sehari satu kapsul.

Kendala yang dihadapi pada ibu hamil trisemester III adalah biaya obat multivitamin yang relatif mahal selama kurang lebih tiga bulan, serta pemeriksaan dokter dan pemeriksaan USG yang relatif mahal. Maka dari itu dibutuhkan studi khusus untuk perhitungan biaya agar lebih efisien. Studi khusus yang mempelajari hal tersebut dikenal dengan nama farmakoekonomi (Trisna, 2010). Kajian farmakoekonomi dengan penghitungan rasio efektivitas-biaya rerata pengobatan (average cost-effectiveness ratios/ACER) seringkali digunakan untuk membandingkan dua atau lebih intervensi kesehatan yang memberikan besaran efek yang berbeda (KL., 2009).

Farmakoekonomi dapat didefinisikan sebagai perhitungan antara biaya yang dikeluarkan dengan dampaknya pada penyembuhan penyakit. Penerapan farmakoekonomi dapat dilakukan untuk mengukur kelebihan suatu obat dibandingkan dengan obat lain berdasarkan analisis farmakoekonomi (Ammari, 2008).

Sejauh ini belum ditemukan penelitian Farmakoekonomi tentang pemberian Multivitamin Pada Masa Kehamilan Trisemester III. Salah satu yang mendekati adalah artikel pada salah satu jurnal penelitian yang berjudul "Hubungan Pemberian Suplemen Zat Besi (Fe) Pada Ibu Hamil Dengan Berat Badan Rendah (BBLR) di RSUD Abdul Wahab Sjahranie Samarinda" (Iriyani, 2017). 
Berdasarkan latar belakang diatas, maka penulis tertarik untuk melakukan penelitian tentang, "Analisis Efektivitas Biaya Multivitamin Pada Masa Kehamilan Trisemester III Pasien Rawat Jalan Di Salah Satu Rumah Sakit Ibu Dan Anak Kota Bandung", yang nantinya diharapkan dapat menjadi acuan untuk menghitung biaya penggunaan multivitamin pada ibu hamil trisemester III.

\section{Metode Penelitian}

Penelitian ini merupakan penelitian analisis kualitatif dengan menggunakan metode analisis farmakoekonomi yang digunakan untuk menganalis Analisis Efektitifitas Biaya (AEB). Analisis Efektifitas Biaya dinyatakan dengan Rasio Efektifitas Biaya (REB) rata-rata (Average Cost Effectiveness Ratio/ACER) atau sebagai Rasio Efektifitas Biaya tambahan (Incremental Cost- Effectiveness Ratio/ICER) (Andayani, 2013). REB adalah perhitungan rasio biaya rerata yang digunakan untuk membandingkan biaya yang dikeluarkan antara penggunaan dua intervensi yang berbeda dengan tujuan yang sama dengan memasukan data biaya (cost) dan hasil pengobatan (outcome) kedalam rasio pada kedua atau lebih obat tersebut (KemenKes RI, 2013). Dengan hasil outcome yang dilakukan dengan menggunakan USG yang digunakan untuk mengukur efektifitas terapi multivitamin yang diberikan pada pasien ibu hamil dengan melihat kenaikan berat badan janin, dimana ibu hamil memiliki berat badan janin yang ideal (2.500 gram-4.000 gram). Data yang diambil dari setiap pasien merupakan data penambahan berat badan janin selama pemberian terapi multivitamin pada pasien Kehamilan Trisemester III. Dengan kriterian Obat yang akan dianalisis adalah multivitamin yang digunakan dengan dosis yang diberikan pada kedua alternatif tersebut adalah $1 \mathrm{x}$ sehari setelah makan, sebagai terapi pada pasien kehamilan trisemester III. Analisis statistik yang digunakan dalam penelitian ini adalah untuk mengetahui perbedaan signifikan atau tidaknya kelompok biaya dan outcome pemberian multivitamin pada Kehamilan Trisemester III di Rumah Sakit Ibu dan Anak Humana Prima.

\section{Hasil dan Pembahasan}

\section{A. Distribusi Populasi Dan Sampel}

Pengumpulan data dilakukan dari bulan Mei - Juli 2019 di bagian Rekam Medikdi salah satu Rumah Sakit Ibu dan Anak Kota Bandung. Dari hasil penelitian tercatat 104 pasien yang mendapatkan terapi multivitamin pada trisemester III selama tahun 2018 yang memenuhi kriteria inklusi.

Pada penelitian ini jumblah pasien terbanyak yaitu pada umur 26-30 tahun sebanyak 42 orang. Umumnya pada usia tersebut secara mental sudah jauh lebih siap yang akan berdampak pada prilaku merawat dan menjaga kehamilannya secara hati-hati. Data bisa dilihat pada Tabel 1 dan Gambar 1 dibawah : 
Tabel 1

Jumlah Pasien Berdasarkan Umur

\begin{tabular}{cccc}
\hline No & Umur & Pasien & $\%$ \\
\hline 1. & $21-25$ tahun & 34 & 33 \\
\hline 2. & $26-30$ tahun & 42 & 40 \\
\hline 3. & $31-35$ tahun & 28 & 27 \\
\hline & Jumlah & 104 & $100 \%$ \\
\hline
\end{tabular}

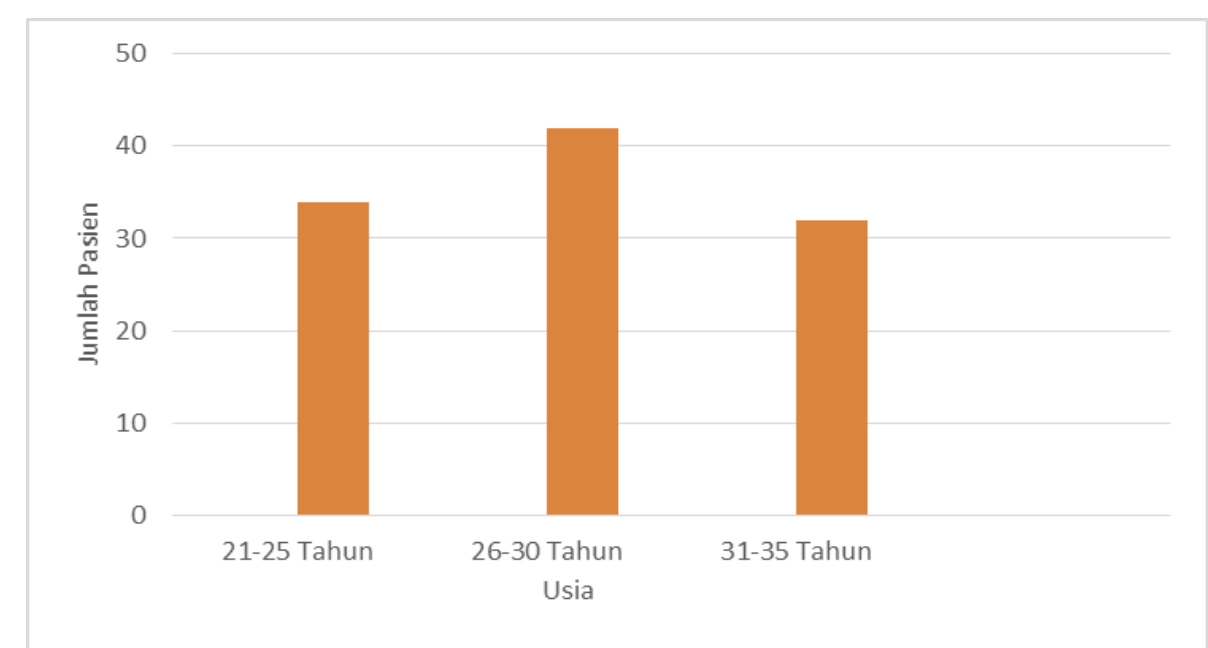

Gambar 1

Jumlah Pasien Berdasarkan Umur

Sedangkan dari hasil penelitian yang dilakukan bahwa jumblah pasien ibu hamil trisemester III lebih banyak mendapatkan terapi obat multivitamin Iberet ${ }^{\circledR}$ Folic, pada usia Kehamilan Trisemester III tersebut sangat penting untuk ibu hamil mengkonsumsi zat besi. Alasannya adalah dapat membantu mencegah kelahiran prematur dan juga untuk menghindari anemia pada ibu hamil karena dapat meningkatkan resiko Bayi Berat Lahir Rendah (BBLR). Data bisa dilihat pada Tabel 2 dan Gambar 2 dibawah:

Tabel 2

Data Pasien Kehamilan Trisemester III

\begin{tabular}{clcc}
\hline No & \multicolumn{1}{c}{ Jenis Obat } & Pasien & $\%$ \\
\hline 1. & Prenamia $^{\circledR}$ & 21 & 20 \\
\hline 2. & Iberet $^{\circledR}$ Folic 500 & 42 & 41 \\
\hline 3. & Folamil Genio $^{\circledR}$ & 41 & 39 \\
\hline & Jumlah & 104 & $100 \%$ \\
\hline
\end{tabular}




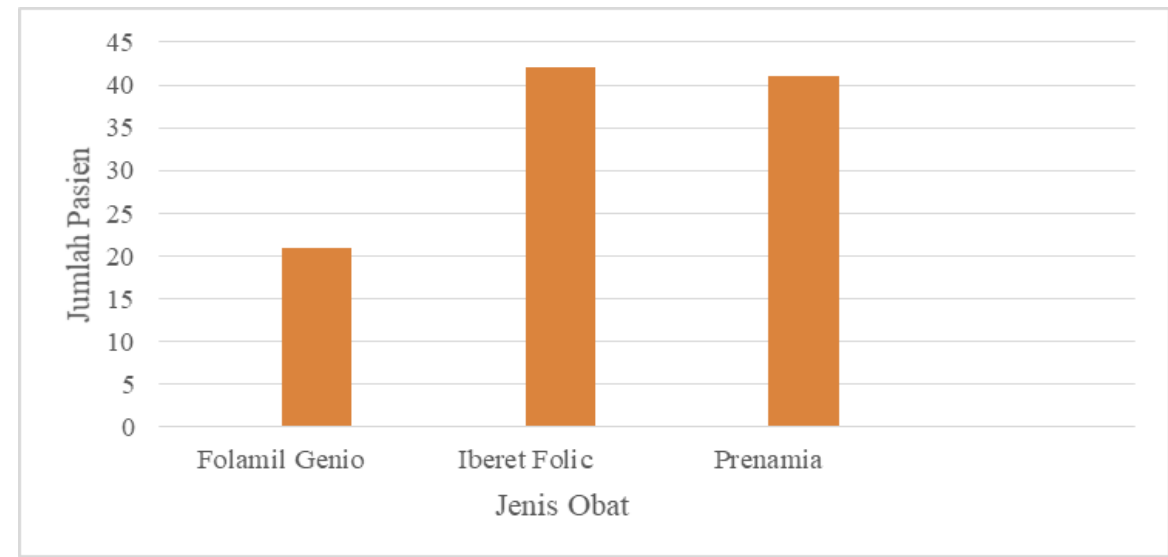

Gambar 2

Data Pasien Kehamilan Trisemester III

\section{B. Hasil Penentuan outcome}

\section{Penentuan Outcome Setiap Alternatif}

Rata-rata kenaikan berat badan janin sampai bayi lahir yang dihasilkan dari masing-masing alternatif dapat terlihat outcome paling tinggi yaitu Prenamia ${ }^{\circledR}$ sebesar 2.018 gr. Salah satu penyebabnya selain terapi multivitamin bisa didukung dengan makanan yang dikonsumsi oleh ibu hamil selama kehamilan sampai trisemester III dan melahirkan. Data dapat dilihat dari Tabel 3 dan Gambar 3 dibawah ini :

\section{Tabel 3}

Kenaikan Berat Badan Janin Sampai Lahir Rata-rata Kenaikan BB

Nama Obat Jumlah Kenaikan Jumlah Janin (Jml Kenaikan/Jml BB Janin (gr) Pasien Pasien)

\begin{tabular}{llll} 
& & & $(\mathrm{gr})$ \\
\hline Prenamia $^{\circledR}$ & 82.762 & 41 & 2.018 \\
\hline Iberet $^{\circledR}$ Folic & 78.045 & 45 & 1.858 \\
\hline Folamil Genio $^{\circledR}$ & 38.160 & 21 & 1.817 \\
\hline
\end{tabular}




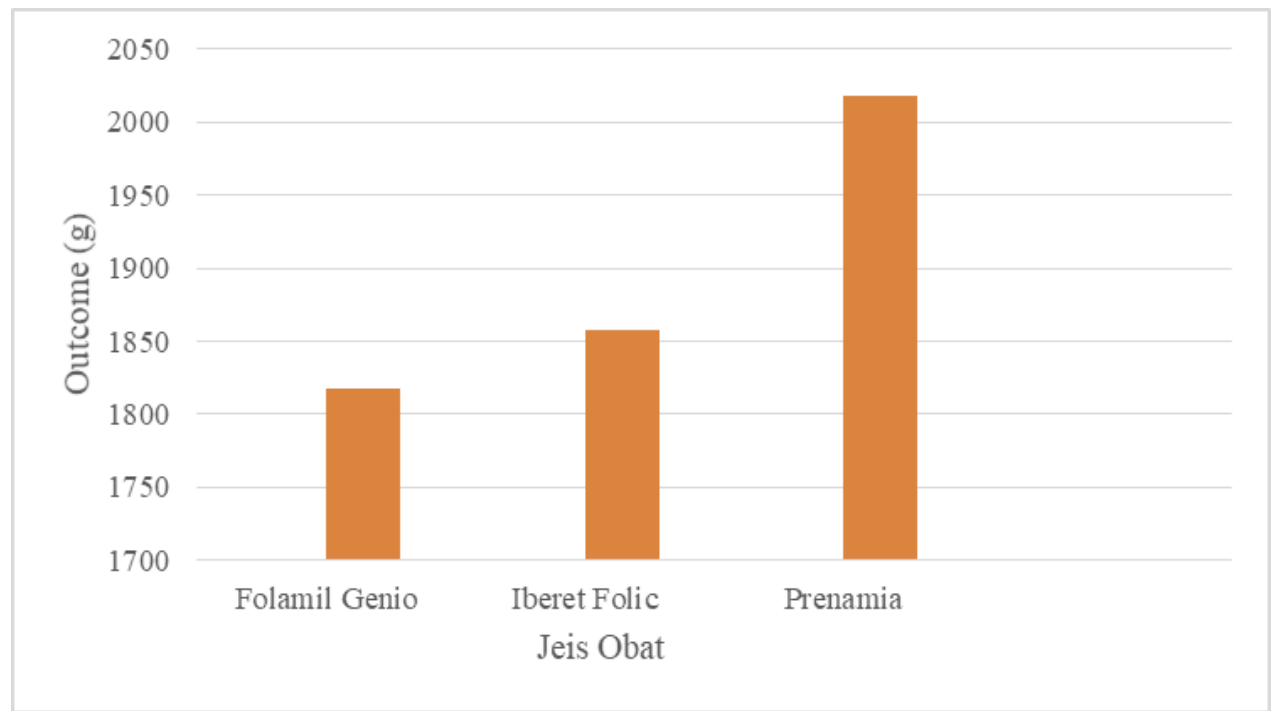

Gambar 3

Data Rata-rata Kenaikan Berat Badan Janin Sampai Lahir

\section{Analisis Statistik Outcome}

Sebelum dilakukannya analisis statistik outcome pengobatan,dilakukan uji normalitas data terlebih dahulu untuk mengetahui hasil distribusi data dari penelitian.Jika hasil uji normalitas berdistribusi normal maka analisis statistik yang akan dilakukan adalah statistik parametrik, namun jika hasil uji normalitas data tidak berdistribusi normal maka analisis statistik yang dilakukan adalah statistik non parametrik. Didapatkan hasil sebagai berikut :

Tabel 4

Hasil Uji Normalitas Outcome

\begin{tabular}{lccc}
\hline & \multicolumn{3}{c}{ Tests of Normality } \\
\hline & \multicolumn{3}{c}{ Kolmogorov-Smirnov } \\
\cline { 2 - 4 } Jenis Obat & Statistic & Df & Sig. \\
& & & \\
\hline Prenamia $^{\circledR}$ & 0,874 & 40 & 0,021 \\
\hline Iberet folic $^{\circledR}$ & 0,431 & 41 & 0,074 \\
\hline Folamil Genio $^{\circledR}$ & 0,478 & 21 & 0,049 \\
\hline
\end{tabular}

Karena jumlah sampel lebih dari 50 maka uji yang digunakan yaitu Kolmogorov-smirrov.

Kriteria pengujian :

Distribusi normal : bila nilai sig. $>0,05$

Tidak berdistribusi normal : bila nilai sig. $<0,05$

Pada tabel di atas didapat hasil untuk jenis terapi atau jenis obat menunjukkan data berdistribusi normal. Hal ini dikarenakan nilai signifikan pada ketiga sampel uji $>0,05$. 
Data hasil uji statistik normalitas kolmogorov-smirnov hipotesis ditentukan jika nilai sig $>0,05$ maka data berdistribusi normal dan jika nilai sig $<0,05$ maka data tidak berdistribusi normal. Pada tabel diatas hasil uji normalitas nilai Sig yang diperoleh pada terapi Prenamia ${ }^{\circledR 0,021}$,Iberet folic ${ }^{\circledR}$ 0,074, dan Folamil Genio® 0,049. Diketahui nilai p pada seluruh outcome menunjukkan nilai signifikan $>0,05$ maka data yang digunakan berdistribusi normal maka hasil penelitian ini termasuk kedalam analisis statistik parametrik.

Selanjutnya untuk menentukan kebermaknaan pengaruh pemberian ketiga jenis multivitamin terhadap outcome berupa kenaikan berat badan bayi maka dilakukan uji parametrik one way ANOVA. Didapatkan hasil sebagai berikut :

\section{Tabel 5}

Uji Parametrik One Way ANOVA

\begin{tabular}{lccccc}
\hline & Sum of Squares & df & Mean Square & F & Sig. \\
\hline Between Groups & 45321.220 & 2 & 2266.511 & 43.214 & 0.001 \\
\hline Within Groups & 4217.211 & 104 & 40.550 & & \\
\hline Total & 49538.431 & 106 & & & \\
\hline
\end{tabular}

H0: tidak terdapat perbedaan outcome pada kelompok yang diuji, atau pemberian semua jenis multivitamin uji yang berbeda tidak berpengaruh signifikan terhadap outcome.

$\mathrm{H} 1$ : paling sedikit ada satu $\mu \mathrm{i} \neq 0$; terdapat perbedaan outcome pada kelompok yang diuji, atau pemberian semua jenis multivitamin uji yang berbeda berpengaruh signifikan terhadap outcome ; $\alpha=0,05$.

Uji Dari data tabel di atas, dapat diketahui dalam uji one way anova menunjukkan semua nilai signifikan $<0,05$, maka semua data valid dan menunjukkan bahwa menerima $\mathrm{H} 1$ dan menolak Ho yang artinya terdapat perbedaan outcame pada kelompok yang diuji, atau pemberian semua jenis multivitamin uji yang berbeda berpengaruh signifikan terhadap outcome.

\section{Hasil Penentuan Biaya}

\section{Analisis Biaya Satuan}

Analisis biaya satuan adalah analisi yang menjelaskan biaya semua per produk obat multivitamin yang dibandingkan. Harga Prenamia®Rp. 1.454 lebih rendah dibandingkan dengan harga Iberet®Folic Rp. 4.611 dan Folamil GenioßRp. 4813 dikarenakan ada beberapa kandungan dari masing-masing obat yang berbeda. Data dapat dilihat dari Tabel 4.6 dan Gambar 4.4dibawah :

Tabel 6

Data Harga Satuan Obat

\begin{tabular}{clc}
\hline No & \multicolumn{1}{c}{ Jenis Obat } & Harga Satuan (Rp) \\
\hline 1. & Prenamia $^{\circledR}$ & 1.454 \\
\hline 2. & Iberet folic $^{\circledR}$ & 4.611 \\
\hline 3. & Folamil Genio $^{\circledR}$ & 4813 \\
\hline
\end{tabular}


Efektivitas Biaya Multivitamin pada Masa Kehamilan Trisemester III Pasien Rumah Sakit Ibu dan Anak Kota Bandung

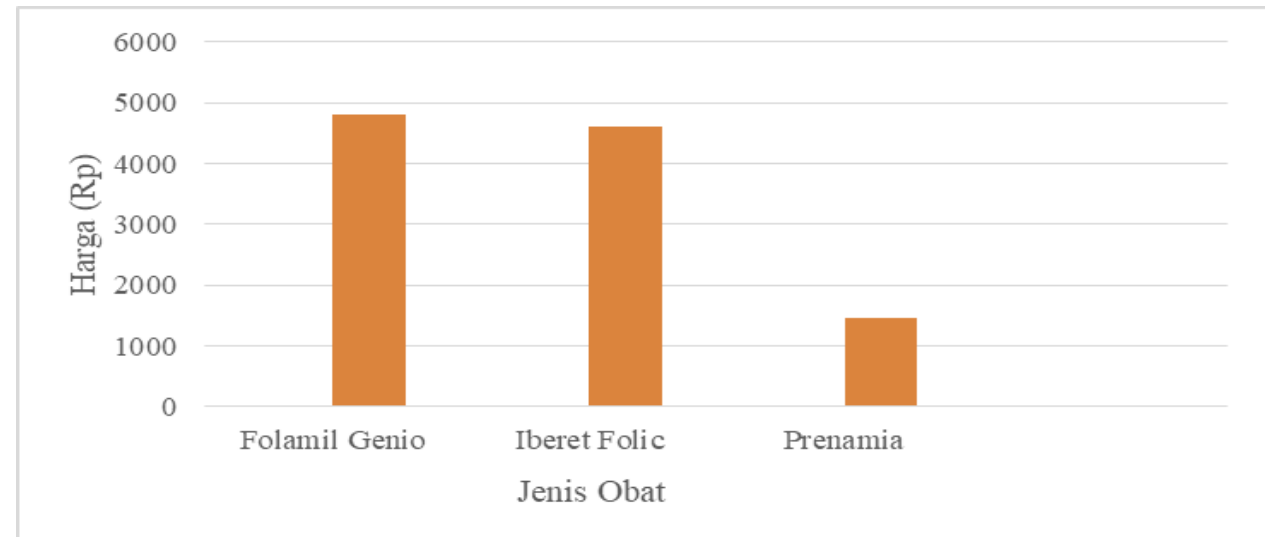

\section{Gambar 4}

Grafik Data Harga Satuan Obat

\section{Analisis Biaya Total}

Biaya total rata-rata setiap terapi yaitu untuk Prenamia® Rp. 128.608, Iberet ${ }^{\circledR F o l i c ~ R p . ~ 409.988, ~ F o l a m i l ~ G e n i o ® ~ R p . ~ 431.566 . ~ D a t a ~ d a p a t ~ d i l i h a t ~ p a d a ~}$ Tabel 7 dan Gambar 5 dibawah ini :

\section{Tabel 7}

Biaya total rata-rata setiap obat

\begin{tabular}{lccc}
\hline Jenis Obat & $\begin{array}{c}\text { Total Biaya } \\
(\mathrm{Rp})\end{array}$ & $\begin{array}{c}\text { Jumlah } \\
\text { Pasien }\end{array}$ & $\begin{array}{c}\text { Rata-rata total biaya } \\
\text { (total biaya/jumlah } \\
\text { pasien) }(\mathrm{Rp})\end{array}$ \\
\hline Prenamia $^{\circledR}$ & 9.062 .879 & 21 & 431.566 \\
\hline Iberet ${ }^{\circledR}$ Folic & 17.219 .510 & 42 & 409.988 \\
\hline Folamil Genio & 5.272 .934 & 41 & 128.608 \\
\hline
\end{tabular}

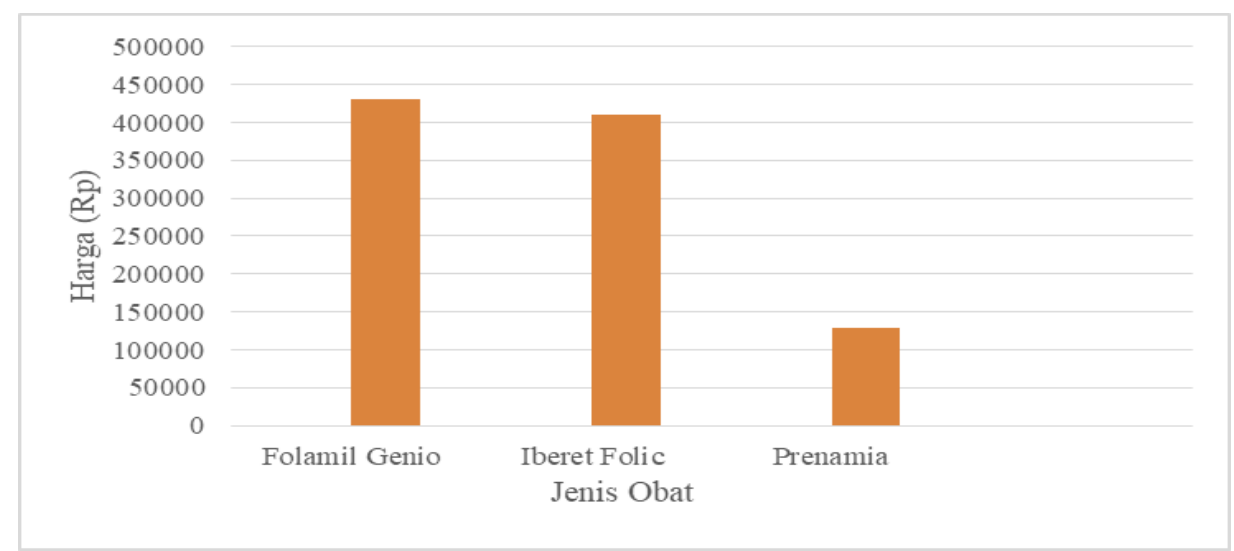

\section{Gambar 5}

Grafik Data Rata-rata Total Biaya Obat

Biaya total rata-rata setiap terapi ditambah pendaftaran, USG, dan pemeriksaan dokter yaitu untuk Prenamia ${ }^{\circledR}$ Rp.1.033.608, Iberet ${ }^{\circledR F o l i c}$ Rp.1.314.988, dan Folamil Genio ${ }^{\circledR}$ Rp.1.336.608. Pemeriksaan dokter selama pemberian multivitamin minimal 3-7 kali pemeriksaan. Data dapat dilihat pada Tabel 8 dan Gambar 6 dibawah ini : 
Tabel 8

Rata-Rata Biaya Total Dan Pemeriksaan Dokter, USG, Pendaftaran

\begin{tabular}{clccc}
\hline No & $\begin{array}{c}\text { Jenis Obat } \\
\text { Multivitamin }\end{array}$ & $\begin{array}{c}\text { Rata rata biaya } \\
\text { total } \\
(\mathrm{Rp})\end{array}$ & $\begin{array}{c}\text { Pemeriksaan dokter, } \\
\text { usg, pendaftaran } \\
(\mathrm{Rp})\end{array}$ & $\begin{array}{c}\text { Total } \\
(\mathrm{Rp})\end{array}$ \\
\hline 1 & Folamil Genio $^{\circledR}$ & 431.566 & 905.000 & 1.336 .566 \\
\hline 2 & Iberet $^{\circledR}$ Folic $^{\circledR}$ & 409.988 & 905.000 & 1.314 .988 \\
\hline 3 & Prenamia $^{\circledR}$ & 128.608 & 905.000 & 1.033 .608 \\
\hline
\end{tabular}

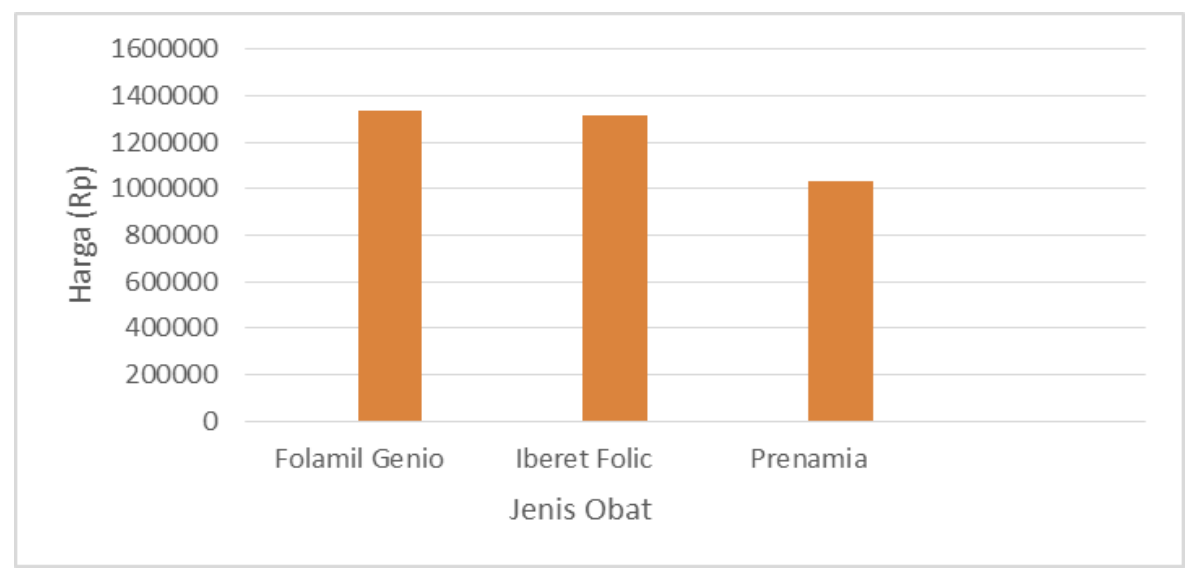

\section{Gambar 6}

\section{Grafik Data Rata-rata Total Biaya Obat dan Pemeriksaan Dokter}

\section{E. Analisis Statistik Biaya}

Analisis statistik biaya adalah analisis yang menjelaskan tentang keseluruhan biaya secara rinci berdasarkan data yang didapatkan dari hasil penelitian dengan menggunakan uji Normalitas. Data dapat dilihat pada Tabel 9 dibawah ini :

Tabel 9

Hasil Analysis of Varians (ANOVA)

\begin{tabular}{|c|c|c|c|c|c|c|}
\hline \multicolumn{7}{|c|}{ Multiple Comparisons } \\
\hline \multicolumn{7}{|c|}{$\begin{array}{c}\text { Dependent Variable: Total Biaya } \\
\text { Tukey HSD }\end{array}$} \\
\hline \multirow{2}{*}{$\begin{array}{l}\text { (I) Jenis } \\
\text { Obat }\end{array}$} & \multirow{2}{*}{$\begin{array}{c}\text { (J) Jenis } \\
\text { Multivitamin }\end{array}$} & \multirow{2}{*}{$\begin{array}{c}\text { Mean } \\
\text { Difference } \\
\text { (I-J) }\end{array}$} & \multirow[t]{2}{*}{ Std. Error } & \multirow[t]{2}{*}{ Sig. } & \multicolumn{2}{|c|}{ 95\% Confidence Interval } \\
\hline & & & & & $\begin{array}{l}\text { Lower } \\
\text { Bound }\end{array}$ & $\begin{array}{l}\text { Upper } \\
\text { Bound }\end{array}$ \\
\hline \multirow[t]{3}{*}{ Prenamia $^{\circledR}$} & Prenamia $^{\circledR}$ & & & & & \\
\hline & Iberet ${ }^{\circledR}$ Folic & $46267,38^{*}$ & 31245,45 & ,001 & 750007,52 & 105512,11 \\
\hline & $\begin{array}{l}\text { Folamil } \\
\text { Genio }^{\circledR}\end{array}$ & $51896,40^{*}$ & 30478,32 & ,000 & 43231,54 & 82348,36 \\
\hline \multirow{3}{*}{$\begin{array}{l}\text { Iberet } \\
\text { folic }\end{array}$} & Prenamia ${ }^{\circledR}$ & $-60198,17^{*}$ & 41327,40 &, 003 & 12357,82 & 3231,75 \\
\hline & Iberet ${ }^{\circledR}$ Folic & & & & & \\
\hline & $\begin{array}{l}\text { Folamil } \\
\text { Genio }^{\circledR}\end{array}$ & $38940,20^{*}$ & 35478,12 & ,002 & 5894,61 & 34218,11 \\
\hline \multirow{3}{*}{$\begin{array}{l}\text { Folamil } \\
\text { Genio }^{\circledR}\end{array}$} & Prenamia $^{\circledR}$ & $63241,12^{*}$ & 60785,21 & 007 & 35628,39 & 464209,80 \\
\hline & Iberet ${ }^{\circledR}$ Folic & $65420,41^{*}$ & 45212,022 &, 000 & 21238,11 & 423458,61 \\
\hline & $\begin{array}{l}\text { Folamil } \\
\text { Genio }^{\circledR}\end{array}$ & & & & & \\
\hline
\end{tabular}


H0: tidak terdapat perbedaan biaya pada kelompok yang diuji, atau pemberian semua jenis multivitamin uji yang berbeda tidak berpengaruh signifikan terhadap biaya

H1: paling sedikit ada satu $\mu \mathrm{i} \neq 0$; terdapat perbedaan biaya pada kelompok yang diuji, atau pemberian semua jenis multivitamin uji yang berbeda berpengaruh signifikan terhadap biaya; $\alpha=0,05$.

Uji Dari data tabel di atas, dapat diketahui dalam uji one way anova menunjukkan semua nilai signifikan $<0,05$, maka semua data valid dan menunjukkan bahwa menerima $\mathrm{H} 1$ dan menolak Ho yang artinya terdapat perbedaan biayapada kelompok yang diuji, atau pemberian semua jenis multivitamin uji yang berbeda berpengaruh signifikan terhadap biaya.

Maka uji Anova dilanjutkan ketahap Post Hoc.Didapatkan hasil sebagai berikut :

Tabel 10

Hasil Uji Post hoc Tukey

\begin{tabular}{lrrr}
\hline \multicolumn{4}{c}{ Total Biaya } \\
\hline Tukey HSD & N & Subset \\
\cline { 3 - 4 } & & 1 & 2 \\
\hline Jenis Obat & 41 & 64534,4 & \\
\hline Prenamia $^{\circledR}$ & & 4 & 21234,90 \\
& 42 & & 34532,10 \\
\hline Iberet $^{\circledR}{ }^{\text {Folic }}$ & 22 & & 0,324 \\
\hline Folamil Genio $^{\circledR}$ & & 1,000 & \\
\hline Sig. & & & \\
\hline
\end{tabular}

Dari data tabel di atas dapat diketahui bahwa jenis mutivitamin Prenamia® menunjukkan perbedaan signikan terhadap jenis obat yang lainnya.

\section{F. Rasio Efektivitas Biaya}

Rasio efektivitas biaya dihitung dengan cara membandingkan biaya penggunaan obat multivitamin pada kehamilan Trisemester III dengan nilai efektivitas atau outcome klinis berdasarkan data yang dihasilkan. Efektivitas biaya dianalisis dengan rumus rasio efektivitas biaya rerata pengobatan (REB) yang dihitung berdasarkan biaya total terhadap kenaikan berat badan janin sampai bayi lahir. Hasil analisa dapat dilihat pada Tabel 11 dan Gambar 7 dibawah ini :

Tabel 11

Nilai REB(ACER) Penggunaan Obat Multivitamin

\begin{tabular}{clccc}
\hline No & $\begin{array}{c}\text { Jenis Obat } \\
\text { Multivitamin }\end{array}$ & Biaya (Rp) & Outcome (gr) & REB (Rp/gr) \\
\hline 1 & Prenamia $^{\circledR}$ & 1.033 .608 & 2018 & 512,19 \\
\hline 2 & Iberet $^{\circledR}$ Folic $^{(}$ & 1.314 .988 & 1858 & 707,74 \\
\hline 3 & Folamil Genio $^{\circledR}$ & 1.336 .608 & 1817 & 735,61 \\
\hline
\end{tabular}




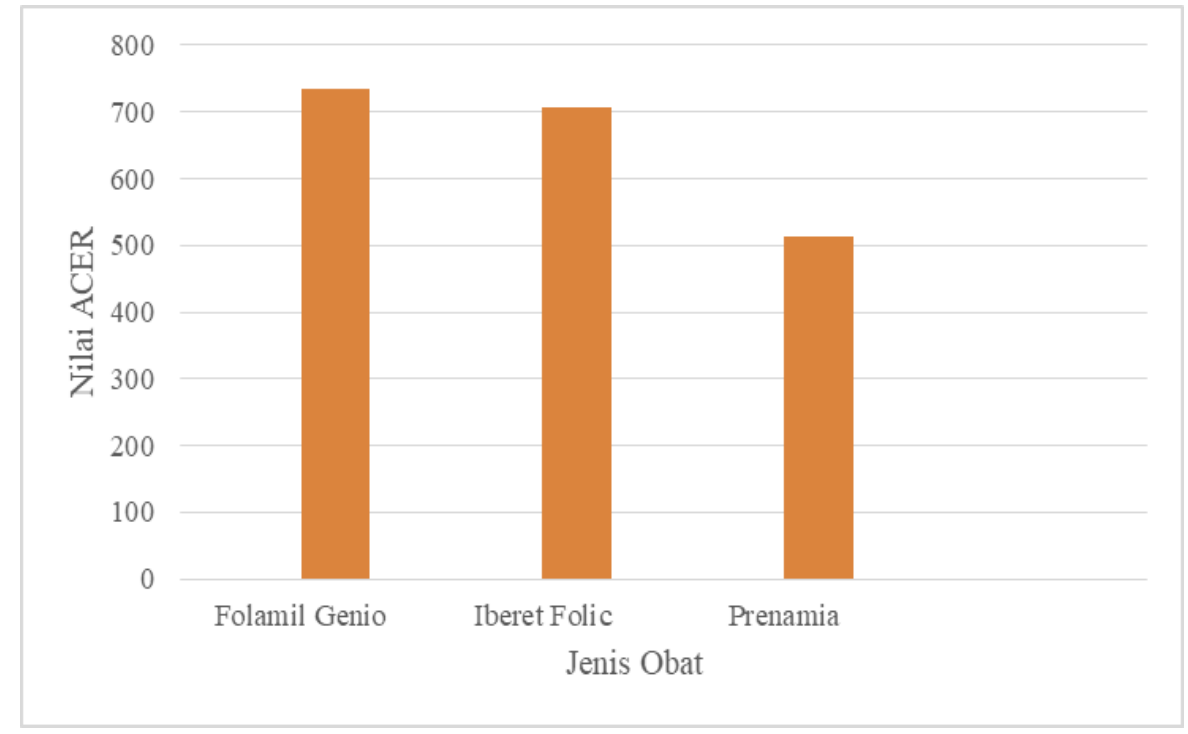

\section{Gambar 7 \\ REB Penggunaan Obat Multivitamin}

Setelah Melakukan perhitungan dengan menggunakan REB untuk mengetahui efektivitas biaya dari pilihan terapi multivitamin pada ibu hamil trisemester III yang menggunakan multivitamin Prenamia®memiliki efektivitas Rp. 512,19/gr, Iberet巴 Folic Rp. 707,74/gr, dan untuk Folamil Genio®Rp. 735,61, sehingga dapat diketahui multivitamin Iberet ${ }^{\circledR}$ Folic memiliki efektivitas biaya besar dengan outcome tinggi dibandingan dengan Prenamia ${ }^{\circledR}$ dan Folamil Genio ${ }^{\circledR}$. Hal tersebut dipengaruhi oleh outcome masing-masing obat multivitamin tersebut.

\section{G. Tabel Efektivitas Biaya}

Pada Kolom C (juga kolom B dan F) dimana efektivitas lebih rendah dengan biaya sama (kolom B) atau efektivitas sama dengan biaya tinggi (kolom F) apalagi efektivitas lebih rendah dengan biaya lebih tinggi (kolom $\mathrm{C}$ ), tidak perlu dipertimbangkan sebagai alternatif tidak perlu diikutsertakan dalam perhitungan AEB, posisi seimbang kolom E suatu intervensi kesehatan yang menawarkan efektivitas dan biaya yang sama (kolom E) masih boleh dipilih. Dan untuk posisi yang memerlukan pertimbangan efektivitas-biaya adalah kolom A dan I, dimana jika suatu intervensi kesehatan yang menawarkan efektivitas yang lebih rendah dengan biaya yang lebih rendah pula (kolom A), sebaliknya jika efektivitas menawarkan efektivitas yang lebih tinggi dengan biaya yang lebih tinggi (kolom I) untuk melakukan pemilihan perlu memperhitungkan RIEB (Menkes, 2013). 
Efektivitas Biaya Multivitamin pada Masa Kehamilan Trisemester III Pasien Rumah Sakit Ibu dan Anak Kota Bandung

Tabel 12

Kelompok Alternatif Berdasarkan Efektivitas-Biaya

\begin{tabular}{|c|c|c|c|}
\hline $\begin{array}{c}\text { Efektivitas } \\
\text { biaya }\end{array}$ & Biaya lebih rendah & $\begin{array}{c}\text { Biaya } \\
\text { sama }\end{array}$ & Biaya lebih tinggi \\
\hline $\begin{array}{l}\text { Efektivitas } \\
\text { lebih } \\
\text { rendah }\end{array}$ & A & B & $\begin{array}{l}\text { Folamil Genio }{ }^{\circledR} \text { terhadap } \\
\text { Iberet }^{\circledR} \text { Folic } 500 \\
\text { Iberet }^{\circledR} \text { Folic } 500 \text { terhadap } \\
\text { Prenamia }\end{array}$ \\
\hline $\begin{array}{l}\text { Efektivitas } \\
\text { sama }\end{array}$ & $\mathrm{D}$ & $\mathrm{E}$ & $\mathrm{F}$ \\
\hline $\begin{array}{l}\text { Efektivitas } \\
\text { lebih tinggi }\end{array}$ & $\begin{array}{l}\text { Prenamia }^{\circledR} \text { terhadap } \\
\text { Iberet }^{\circledR} \text { Folic } 500 \\
\text { Prenamia }{ }^{\circledR} \text { terhadap } \\
\text { Folamil Genio }^{\circledR}\end{array}$ & $\mathrm{H}$ & $\begin{array}{c}\text { I } \\
\text { (Perlu Perhitungan RIEB) }\end{array}$ \\
\hline
\end{tabular}

Pada tabel efektivitas biaya antara miltivitamin Prenamia ${ }^{\circledR}$, Iberet ${ }^{\circledR}$ Folic 500, dan Folamil Genio®, dapat dililhat bahwa miltivitamin Prenamia®menunjukkanbiaya lebih rendah tetapi efektivitasnya lebih tinggi dibandingkan dengan Iberet® Folic 500, dan Folamil Genio®.

\section{Kesimpulan}

Berdasarkan hasil penelitian yang telah dilakukan dengan analisis efektivitas biaya antara pasien Kehamilan Trisemester III di salah satu Rumah Sakit Ibu dan Anak Kota Bandung, maka dapat diambil kesimpulan bahwa pasien ibu hamil terbanyak pada penelitian Trisemester III paling banyak berusia 26-30 tahun. Terapi multivitamin dengan rasio efektivitas biaya (REB) terendah yaitu Prenamia ${ }^{\circledR}$ Rp. 512.19/gr dan hasil analisis statistik outcome dengan uji oneway anova menunjukkan semua nilai signifikan $<0,05$, artinya terdapat perbedaan outcome pada kelompok yang diuji, atau pemberian semua jenis multivitamin uji yang berbeda berpengaruh signifikan terhadap outcome. 


\section{BIBLIOGRAFI}

Altahira, Sutrisna. (2014). Asuhan Kebidanan (kehamilan). Bau bau: akbidykin.

Ammari, Jala. (2008). Hubungan Kualitas Pelayanan Farmasi Pasien Rawat Jalan Terhadap Kepuasan Dan Keputusan Beli Ulang Obat Di Ifrs Jala Ammari Makassar.

Andayani, Tri Murti. (2013). Farmakoekonomi prinsip dan metodologi. Yogyakarta: Bursa Ilmu, 3-37.

Dinas Kesehatan. (2016). Profil Kesehatan Provinsi Jawa Barat., Bandung .hal 102.

Glynn, Keva, Maclean, Heather, Forte, Tonia, \& Cohen, Marsha. (2009). The association between role overload and women's mental health. Journal of Women's Health, 18(2), 217-223.

Hobel, Calvin, \& Culhane, Jennifer. (2003). Role of psychosocial and nutritional stress on poor pregnancy outcome. The Journal of Nutrition, 133(5), 1709S-1717S.

Iriyani, K. (2017). Hubungan Pemberian Suplemen Zat Besi (Fe) Pada Ibu Hamil Dengan Berat Badan Lahir Rendah (BBLR) Di RSUD Abdul Wahab Sjahranie Samarinda. Jurnal Ilmiah Manuntung, 2(1), 56-59.

KL., Rascati. (2009). Essentials of pharmacoeconomics. Philadelphia: Lippincott Williams \& Wilkies.

Little, George A., Keenan, William J., Niermeyer, Susan, Singhal, Nalini, \& Lawn, Joy E. (2011). Neonatal nursing and helping babies breathe: an effective intervention to decrease global neonatal mortality. Newborn and Infant Nursing Reviews, 11(2), $82-87$.

Manuaba, Ida Bagus Gde, Manuaba, I. A. Chandranita, \& Manuaba, IBGF. (2007). Pengantar kuliah obstetri. Jakarta: Egc, 450-455.

Maulana, Mirza. (2008). Panduan Lengkap Kehamilan. Jogyakarta: Kata Hati.

Menkes, R. I. (2013). Pedoman Penerapan Kajian Farmakoekonomi. Direktorat Jenderal Bina Kefarmasian Dan Alat Kesehatan. Jakarta.

RI, Kemenkes. (2012). Kerangka Kebijakan Gerakan Sadar Gizi Dalam Rangka Seribu Hari Pertama Kehidupan (1000 HPK). Jakarta: Kementerian Kesehatan Republik Indonesia.

Trisna, Yilia. (2010). Aplikasi Farmakoekonomi. Materi Perkembangan Farmasi Nasional. Ikatan Apoteker Indonesia, Jakarta 